\title{
The Effect of Fluoride on the Developing Tooth
}

\author{
C. Robinson ${ }^{a}$ S. Connell ${ }^{a} \quad$ J. Kirkham ${ }^{a}$ S.J. Brookes ${ }^{a} \quad$ R.C. Shore ${ }^{a}$ \\ A.M. Smith ${ }^{b}$ \\ a Leeds Dental Institute, and b Department of Physics and Astronomy, University of Leeds, Leeds, UK
}

\section{Key Words}

Apatite - Cell structure - Enamel · Fluoride · Fluorosis · Proteases $\cdot$ Protein-matrix

\begin{abstract}
This review aims to outline the effects of fluoride on the biological processes involved in the formation of tooth tissues, particularly dental enamel. Attention has been focused on mechanisms which, if compromised, could give rise to dental fluorosis. The literature is extensive and often confusing but a much clearer picture is emerging based on recent more detailed knowledge of odontogenesis. Opacity, characteristic of fluorotic enamel, results from incomplete apatite crystal growth. How this occurs is suggested by other changes brought about by fluoride. Matrix proteins, associated with the mineral phase, normally degraded and removed to permit final crystal growth, are to some extent retained in fluorotic tissue. Fluoride and magnesium concentrations increase while carbonate is reduced. Crystal surface morphology at the nano-scale is altered and functional ameloblast morphology at the maturation stage also changes. Fluoride incorporation into enamel apatite produces more stable crystals. Local supersaturation levels with regard to the fluoridated mineral will also be elevated facilitating crystal growth. Such changes in crystal chemistry and morphology, involving stronger ionic and hydrogen bonds, also lead to greater binding of modulating matrix proteins and proteolytic enzymes. This results in reduced
\end{abstract}

degradation and enhanced retention of protein components in mature tissue. This is most likely responsible for porous fluorotic tissue, since matrix protein removal is necessary for unimpaired crystal growth. To resolve the outstanding problems of the role of cell changes and the precise reasons for protein retention more detailed studies will be required of alterations to cell function, effect on specific protein species and the nano-chemistry of the apatite crystal surfaces.

Copyright $@ 2004$ S. Karger AG, Basel

Fluoride ion has played a major role in dramatically reducing dental caries over the past 40 years. The discovery was made by comparing caries incidence in individuals exposed to so-called high-fluoride water supplies with that in individuals exposed to lower levels [Dean et al., 1942]. It was deduced from these data that fluoride exposure during tooth development was a prime cause of caries reduction. Since teeth from high-fluoride areas had accumulated higher concentrations of fluoride compared with those from low-fluoride areas, fluoride content of the dental tissues was cited as a major factor in reduced caries incidence.

The effect of fluoride on the dentition is dose-dependent and is not confined to increased caries resistance. Above certain levels in the water supply, visible changes to the teeth, particularly the enamel, become evident. This is the condition known as dental fluorosis.

\section{KARGER \\ Fax +4161306 1234 \\ E-Mail karger@karger.ch \\ www. karger.com

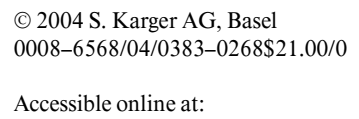

Prof. C. Robinson

Division of Oral Biology, Leeds Dental Institute

Clarendon Way

Leeds LS2 9LU (UK)

Tel./Fax +44 113233 6158, E-Mail C.Robinson@leeds.ac.uk 


\section{Visible Effects of Fluoride on Dental Enamel}

The effects of fluoride on dental enamel are well documented [Dean and Elvolve, 1937; Fejerskov et al., 1977; Thylstrup and Fejerskov, 1978]. At about 1 ppm fluoride $(53 \mu M)$ in the water supply, visible signs of fluorosis begin to become obvious on the enamel surface as opacities, implying some porosity in the tissue. As dose increases, these become more obvious until at $10 \mathrm{ppm}$ $(530 \mu M)$ or so, the porosity is such that the enamel is physically compromised and large pieces may be fractured from the tooth especially after eruption. The porosity appears to derive from incomplete crystal growth such that the normal close juxtaposition and interlocking of crystals does not occur.

\section{Selective Effect of Fluoride on the Mineralised Tissues}

The reasons for the apparent selective effect of fluoride on the skeletal and dental tissues and enamel in particular have been related to the interaction between fluoride ions and the skeletal mineral, calcium hydroxyapatite, dealt with in detail below.

Fluoride is the most electronegative of the elements and is of small ionic diameter. Its resulting high charge density endows it with a great capacity to form strong ionic and hydrogen bonds. This provides the fluoride ion with a potential for interacting both with mineral phases and organic macromolecules. Because of these properties, particularly its small size, it can also act as a 'structure former' in water. This can decrease the mobility of water molecules in solution and in hydration layers of proteins and apatite surfaces with concomitant effects on ligand binding and exchange.

Interactions with the mineral phase have two kinds of effect. First a direct effect on the properties of the mineral itself and its relationship with the enveloping and modulating extracellular organic matrix. Second, the selective concentration of fluoride at the surfaces of mineralised tissues [Robinson et al., 1996] may give rise to elevated fluoride in the immediate vicinity of mineralised tissue cells such that local concentrations may be much higher than those of the tissue fluids in general.

Information on local fluoride concentrations in tissue fluids is limited, however, especially in the immediate neighbourhood of fluoridated apatite. In the enormous amount of work which has been carried out the actual concentrations responsible for any given effect are perhaps the most difficult of areas to clarify. Plasma fluoride concentrations seem to be of particular relevance, relating closely to dietary supply and being around $1 \mu M$ at $53 \mu M$ in the water supply rising to about $4 \mu M$ at $265 \mu M$ [Guy et al., 1976; Speirs, 1986]. Wherever possible, therefore, plasma concentrations or those in the immediate tissue environment such as enamel fluid or culture medium have been quoted.

\section{Site(s) of Action of the Fluoride Ion during Odontogenesis}

While the effects of fluoride on odontogenesis are well established, the precise site(s), stage(s) of development, timing, and mechanism of action are still unclear. The most likely sites are: (a) cells of the tooth-forming tissues: proliferation, differentiation, functional morphology; (b) extracellular matrix of tooth tissues: matrix protein synthesis secretion, processing and loss; (c) mineral phase: initiation, crystal growth, chemical properties, and (d) extracellular matrix-mineral interactions in tooth tissues.

\section{Effect of Fluoride on Odontogenic Cells}

\section{Stage of Fluoride Uptake}

In enamel, long considered to be the most susceptible of the dental tissues, fluoride accumulates throughout the developing tissue but especially at its surface. This occurs selectively both very early in amelogenesis and later, across the transition/maturation stage border [Weatherell et al., 1975, 1977]. At this late stage, full tissue thickness has been achieved; the supporting extracellular matrix largely replaced by fluid and considerable growth in crystal thickness begins. Selective uptake may thus be due to the highly porous, hydrated nature of this developmental stage [Hiller et al., 1975; Robinson et al., 1981, 1988]. Substantial amounts of fluoride are then lost during subsequent maturation. This implies that much of this fluoride may be labile and together with the reported lowering of $\mathrm{pH}$ at this stage, which would dissolve mineral surfaces [Sasaki et al., 1991], locally elevated fluoride concentrations are likely. Cells associated with matrix withdrawal and crystal growth during maturation could thus be exposed to locally high fluoride concentrations. Suggestions that fluorosis can be induced by elevating concentrations only at this latter stage are consistent with these data [Richards et al., 1986]. While efforts to determine fluoride concentrations in enamel fluid have been made [1 $\mu M$, Aoba and Moreno, 1987], this did not distinguish 
between developmental stages and must be regarded as an average.

\section{Cell Proliferation}

Work with tissue culture using 'pre-ameloblasts' has so far revealed no alterations in DNA synthesis at fluoride concentrations up to $1.31 \mu M$ [Bronckers and Wöltgens, 1985] or in frequency of mitotic figures at concentrations up to $1.06 \mathrm{~m} M$ [Lyaruu et al., 1986].

While the effect of fluoride on proliferating odontogenic cells is equivocal, it is worth noting that bone cells in culture have shown sustained mitosis in response to fluoride [Wergedal et al., $1988(20 \mu M)$; Khokher and Dandona, $1990(>250 \mu M)$ ]. This was attributed to intracellular signalling pathways associated with mitotic activity. Inhibition by fluoride, of tyrosine phosphorylase phosphatase, part of the mitogen-activating protein kinase (MAPK) system, has received particular attention [Lau and Baylink, 1990] together with activation of $G$ proteins which stimulate protein kinase $C$. Inhibition of this phosphatase would tend to sustain mitotic activity by maintaining levels of active tyrosine phosphorylase, a mediator of mitotic activity. Why ameloblasts have not shown increased mitosis is not clear. The effect indicated may be specific to bone cells. However, dividing ameloblasts may already be near maximum 'mitotic activity' during tooth formation and any increase over such high activity may not be discernible. Such modest enhancement of mitosis might, however, be in part responsible for alterations to tooth size and morphology attributed to fluoride [Cooper and Ludwig, 1965].

\section{Cell Differentiation and Functional Morphology}

Almost no effects of fluoride on odontogenic cell differentiation were detected at $\sim 50 \mu M$ peak plasma fluoride concentrations [Walton and Eisenmann, 1974] and up to $265 \mu M$ in culture medium [Bronckers et al., 1984a], although at higher concentrations $(3 \mathrm{mM})$ a delay in differentiation was reported [Kerley and Kollar, 1977 .

While not strictly an effect on differentiation, effects on ameloblast cytoskeletal components have been reported recently in abstract form [Gibson et al., IADR Meeting, Gothenburg, 2003]. The amelogenin gene is nested within a RhoGAP gene, which regulates intracellular signalling by activation of $\mathrm{Rho} G$ protein and elevation of $\mathrm{F}$ actin. Fluoride at $4 \mathrm{~m} M$ for 30 min was shown to inactivate RhoGAP, activating Rho and elevating $F$ actin. In ameloblasts this was localised to actin-rich ameloblast cell junctions and Tomes processes.
While this concentration is relatively high, lesser concentrations could affect the dramatic alterations to functional cell morphology and cell-cell interactions which accompany the transformation from secretory to maturation phases and presumably reflect changes in cell function from secretion to maturation. This may explain changes in the periodicity of ameloblast cell membrane modulation which occurs during fluorosis $(10 \mu M \mathrm{~F}$ in plasma) [Denbesten et al., 1985]. The modulation, between smooth and ruffle-ended ameloblasts, is thought to be involved in final crystal growth. This is again especially pertinent since labile fluoride accumulates in enamel precisely at this developmental stage [Weatherell et al., 1975, 1977].

\section{Effect of Fluoride on Matrix Protein Synthesis and Secretion}

The effects of fluoride on cell activity, for example, rate of protein secretion, has been examined but with equivocal results [Denbesten, 1986; Aoba et al., 1990; Robinson and Kirkham, 1990; Aoba and Fejerskov, 2002]. However, a direct effect on matrix composition per se is difficult to discern from data published so far. Only aminoacid compositions have been looked at in detail and no substantial changes due to fluoride have been reported. Since these investigations, a number of distinct protein species have emerged as components of the enamel matrix, e.g. amelogenin, enamelin and ameloblastin together with a number of specific degradative enzymes and other proteins such as albumin and $\alpha \mathrm{HS} 2$ glycoprotein and small amounts of sulphated proteins [for reviews see Robinson et al., 1998a; Fincham et al., 1999]. The effect of fluoride on the relative concentrations of these species, their alternatively spliced variants and/or their individual functions remains to be investigated in detail.

Interpretation of existing data is also complicated by post-synthetic protein processing including post-translational modification and the controlled degradation prior to maturation, which produces a highly consistent pattern of breakdown products [Robinson et al., 1998a; Fincham et al., 1999]. It is therefore difficult to separate effects on protein production per se from effects on post-synthetic or post-secretory activity.

A particular case in point is the level of matrix phosphorylation. Judging from the similarity of ${ }^{32} \mathrm{P}$ uptake and of two-dimensional protein gel patterns between fluoridated and control enamel organ cultures, fluoride up to $1.325 \mathrm{~m} M$ in culture medium had little effect on matrix 
phosphorylation levels [Denbesten, 1986]. This implies little effect of fluoride on either post-translational phosphorylation or any post-secretory dephosphorylation.

The investigation, however, predated the identification of specific phosphorylated proteins of the matrix, in particular enamelin (2\%) [Fukae et al., 1996], which might benefit from further investigation.

\section{Extracellular Matrix Processing and Loss}

A major feature of normal enamel development is the almost complete and selective degradation and loss of enamel matrix proteins, particularly the amelogenins. What remains comprises small peptides, amino acids and insoluble tuft protein [for review see Robinson et al., 1998a]. In mature fluorotic enamel this situation was altered with retention of proline-rich components [Eastoe and Fejerskov, 1984; Wright et al., 1989, 1996]. The precise identity of retained molecular species is unknown but, from their amino acid composition, they did not appear to be intact amelogenin and may be a mixture of degradation products [Wright et al., 1989].

Reports concerning developing fluoridated enamel [Drinkard et al., 1983 (370 $\mu M$ F peak plasma); Denbesten and Crenshaw, 1984; Robinson and Kirkham, 1984b; Denbesten, 1986] revealed a relative increase in $25-\mathrm{kD}$ components in developing enamel containing nascent amelogenin, much of which was mineral-bound [Robinson et al., 2003a]. Smaller components were also retained during maturation, but these data were less clear.

The most likely explanation for these changes is fluoride-induced retention of intact and degraded protein species together with reduced extracellular proteolysis [for review see Robinson and Kirkham, 1990; Aoba and Fejerskov, 2002; Robinson et al., 2003a].

Lowered calcium activity, due to a less soluble mineral phase, has been suggested to slow down proteolysis by $\mathrm{Ca}^{++}$-dependent, secretory stage proteases [Aoba and $\mathrm{Fe}$ jerskov, 2002]. While this is possible, it is unlikely as a major factor. First, given the relatively high calcium levels and small amount of enzyme present, extremely severe reductions in calcium would be necessary. Second, major protein destruction occurs at transition via a serine protease (kallikrein 4) which is not $\mathrm{Ca}^{++}$-dependent [Simmer and $\mathrm{Hu}, 2002]$. Third, the timescale for protein removal and maturation is hugely variable between species. In the rat incisor this is about 2 weeks, in the cow and pig about 2 months, and in human teeth this may take years. These latter periods would appear to be quite sufficient for complete processing and removal of matrix in the order of only hundreds of micrograms [Robinson and Kirkham, 1984a, 1990]. It should also be noted that porcine enamel did not appear to mineralise to the same extent as other species, attaining only $55 \%$ mineral by weight as opposed to $80-90 \%$. This should be borne in mind when using the pig as a model for fluorosis [Kirkham et al., 1988; Robinson and Kirkham, 1990].

Since direct inhibition of enzyme activity has not been demonstrated convincingly [Drinkard et al., 1983; Gerlach et al., 2000], it is likely that enhanced protein interaction with the mineral, described below, is responsible for both protein retention and reduced proteolysis in fluorosed tissue. Increased binding of both undegraded amelogenin [Robinson et al., 2003a] and enamel proteases to the mineral phase [Brookes et al., 1998; Aoba and Fejerskov, 2002] have been reported. This may be especially important at the transition/maturation stage, where final degradation occurs via a specific serine protease (kallikrein 4) and where fluoride accumulates selectively.

\section{Effect of Retained Protein}

The result of fluoride-induced protein retention may also explain the incomplete crystal growth which characterises fluorosis, since it has been demonstrated that matrix removal is a necessary prerequisite for unimpaired crystal growth in enamel [Robinson et al., 1989] and synthetic apatites [Aoba et al., 1987]. In this context, one area worthy of further exploration is the role of ameloblastin. Fluorosis involves incomplete crystal growth at prism peripheries and it is at this site that degradation products of ameloblastin accumulate during development [Uchida et al., 1997; Robinson et al., 1998b]. Impaired removal of ameloblastin due to fluoride could be responsible for incomplete crystal growth in this region.

\section{Effect of Fluoride on the Mineral Phase}

\section{Initiation of Precipitation during Secretion}

While it is established that mature enamel crystals comprise a substituted calcium hydroxyapatite, the precise nature of initial mineral phases, whether in enamel or dentine, is still a matter of some controversy. These range from amorphous short range order calcium phosphates [Posner, 1985] through brushite-like phases to octacalcium phosphate [Brown et al., 1987; Iijima et al., 1992; Johnsson and Nancollas, 1992]. These are often said to be stabilised by carbonate or magnesium. Whatever the nature of this phase, there seems to be general agreement that the presence of fluoride ion during initial deposition can delay formation of an initial apatite precursor, proba- 
bly by stabilising very early precursor entities [Bachra and Fischer, 1969]. Work by Bronckers et al. [1984b] using hamster tooth germs is consistent with this view and showed that protein matrix formed under an elevated fluoride regime did not mineralise at all unless fluoride was removed, indicating a reversible effect on the matrixassociated initiation process.

Precisely how and where initiation occurs is still a matter of discussion. Recently, Robinson et al. [2003c] suggested that crystal formation in enamel may involve fusion of precursor protein/mineral-ion subunits, the established degradative processing of the matrix facilitating initial mineral precipitation. Stabilisation of these protein mineral subunits by fluoride per se would also prevent or delay initiation.

\section{Crystal Growth}

Once the initial mineral phase has formed, fluoride facilitates more rapid deposition [Bachra and Fischer, 1969; Varughese and Moreno, 1981]. This may be due to fluoride-induced conversion of acidic precursors such as amorphous calcium phosphate or octacalcium phosphate to apatite [Iijima et al., 1992]. Perhaps a more likely explanation would be the higher relative supersaturation of tissue fluids with respect to a precipitating fluoridated mineral phase. This would be facilitated by the effect of fluoride in reducing the incorporation of destabilising extraneous ions such as carbonate [Nikiforuk and Grainger, 1965].

Stimulation of crystal growth during early secretion is supported by the work of Bronckers et al. [1984b], who showed, in culture, that with access to fluoride (up to $26.5 \mu M$ ), partially mineralised matrix became hypermineralised. This would be consistent with a more rapid mineral deposition due to a higher relative supersaturation for fluoride-containing mineral. While much in vitro data suggests that fluoride can increase apatite crystal growth in the a and b axes [Eanes and Hailer, 1998], there is little evidence that, at least in enamel, this results in significant alteration to apatite crystal morphology or size [Yanagisawa et al., 1989]. Such changes which have been reported were restricted to the outer enamel and attributed to post-eruptive alterations [Yanagisawa et al., 1989].

\section{Effect of Fluoride on Mineral Properties}

During mineral deposition, fluoride is incorporated into the growing hydroxyapatite crystals either by accretion or by heteroionic substitution.

Fluoride is known to occupy the hydroxyl site in the long $\mathrm{c}$ axis of the crystal. The charge symmetry and high negative charge density allow a better fit in the lattice compared with the larger asymmetric hydroxyl ion. The effects are profound. The sense of the hydroxyl columns is altered such that adjacent hydroxyls will hydrogen bond to the fluoride ion. In addition, protons associated with acid phosphate groups might be more tightly orientated towards the fluoride ion [Posner et al., 1963; Kay et al., 1964; Van der Lugt et al., 1971].

In terms of overall crystal behaviour, energy levels are much reduced. This explains the lower solubility product for fluoridated compared with non-fluoridated mineral and the fact that the crystal is less reactive. With regard to resorption in dentine and dissolution in caries, the fluoridated crystal is much more acid-resistant. In addition, the larger asymmetric substituent, carbonate tends to be excluded from the crystal, further increasing stability [McCann and Bullock, 1957].

Magnesium might be expected to exert a similar effect to carbonate since it does not fit well in the lattice (about $0.2 \%$ maximum). However, an increase in fluoride is usually accompanied by an increase in magnesium content [McCann and Bullock, 1957; Robinson et al., 1983]. This may relate to the fact that magnesium is at highest concentrations during secretion [Hiller et al., 1975] and like fluoride shows some selective uptake during transition [Robinson et al., 1984; Kirkham et al., 1988]. This has been attributed to close affinity of magnesium for fluoride during incorporation into the crystals [Okazaki, 1987]. It may also be surface-located [Neuman and Mulryan, 1971], its higher concentrations being due to specific surface complexes and/or by a greater surface area of the rougher crystal surfaces [Kirkham et al., 2001] (see below).

\section{Matrix-Mineral Interactions}

During enamel maturation, crystal growth, especially in the final stages, is clearly compromised since fluorosis is characterised by greater intercrystalline space, particularly at the prism peripheries [Fejerskov et al., 1977]. Since enamel matrix removal appears to be a prerequisite for normal crystal growth [Aoba et al., 1987; Robinson et al., 1989], impairment of crystal development in vivo has been associated with the demonstrated retention of mineral-bound protein matrix [Drinkard et al., 1983; Denbesten, 1986; Robinson et al., 2003a]. The mechanism of enhanced retention and the molecular species involved (see above) are not yet clear. Fluoridated mineral may bind proteins more effectively [Tanabe et al., 1988] due to

\footnotetext{
$\overline{272} \quad \overline{\text { Caries Res 2004;38:268-276 }}$
} 
greater hydrogen bonding or a less polar surface [Wu and Nancollas, 1999]. Increased magnesium, if located in the Helmholz double layer, could provide cationic bridging for proteins. This does not exclude the possibility that increased magnesium per se could impair growth [Bachra and Fischer, 1969].

More recent work using the atomic force microscope (AFM) has suggested that fluoride could also influence crystal surface morphology and perhaps the mode of crystal growth. This might contribute towards a unifying view of fluoride action. AFM studies of crystal surfaces at the molecular level have indicated that during enamel development, in the rat, the surface roughness of crystals normally decreased in moving from secretion to maturation phases [Kirkham et al., 1998]. This may have resulted from changes in matrix binding but may also reflect a decrease in kink and step site density due to a growth/ healing process perhaps involving a shift from polynuclear towards spiral growth.

Enamel produced under fluorotic conditions, however, did not show such a reduction in roughness. Not only was roughness greater than in non-fluorotic teeth but it was also maintained throughout development [Kirkham et al., 2001]. Since fluoride is taken up selectively during transition and maturation stages [Weatherell et al., 1977], local supersaturation levels would be relatively high in terms of the fluoridated depositing phase. This high supersaturation would favour polynuclear growth and thus increased surface roughening.

Such increased roughening could, together with changes in crystal surface chemistry, account for the increased magnesium typical of fluorosed enamel, a view supported by the fact that magnesium, like fluoride, is selectively taken up at the transition/maturation stage [Hiller et al., 1975; Robinson et al., 1984; Kirkham et al., 1988]. The increased surface area due to roughening could also facilitate protein binding/retention [Gathercole et al., 1996].

Use of the AFM in chemical force mode has also revealed novel information concerning enamel crystal surface properties. Using carboxyl- or hydroxyl-functionalised tips their binding strength to apatite surfaces was measured as a function of $\mathrm{pH}$. This revealed $\mathrm{pK}$ values for apatite surfaces an order of magnitude lower than solution phosphate, implying greater electronegativity. When fluoride was present, binding values were higher and $\mathrm{pK}$ values were even lower, indicating further increased, presumably hydrogen, bonding with phosphate groups or fluoride itself [Robinson et al., 2003b] somewhat similar shifts to those seen in bulk synthetic systems [Wu et al.,1991]. Such studies offer important possibilities for future studies of fluoride-mediated changes to crystal surface properties, not only of crystals, but of the modulating organic matrix.

While much of the consideration of the effect of fluoride resides with its effect on the lattice proper, the roughness findings described above also suggest that the crystal surface/fluid interface should be considered. Given the great propensity for fluoride to form hydrogen bonds it is likely that it could affect ligand binding and exchange with the Helmholz/Gouy-Chapman layers and thus with the lattice itself.

\section{Dentine}

The effect of fluoride on dentine is only detectable at concentrations much higher than those required for enamel fluorosis. Overall effects, however, are similar in that hypomineralisation results [Fejerskov et al., 1979].

\section{Matrix Synthesis and Composition}

While no fluoride-mediated alterations to the main extracellular component, type 1 collagen, have been reported, specific changes to non-collagenous components do occur. Perhaps of greatest current interest is a reported effect on the dentine phosphoproteins [Milan et al., 1999]. Rats rendered fluorotic by dietary fluoride revealed lower molecular sizes for dentine phosphoprotein (phosphophoryn) which, together with lowered phosphate content, was attributed to a lower degree of phosphorylation. Investigations into casein kinase II and alkaline phosphatase - both enzyme types present in developing dentine - also revealed fluoride-mediated inhibition [Milan et al., 2001]. Clearly fluoride is capable of affecting the metabolism of dentine phosphoproteins. The reduction of phosphorylation, in particular, might well decrease mineral ion binding and probably their capacity for crystal initiation.

Analysis of proteoglycans from fluorosed rat dentine in vivo revealed no alterations to the protein core. However, glycosylaminoglycans (GAGs) appeared to be smaller and more anionic, possibly due to the additional presence of dermatan and heparan sulphate [Hall et al., 1996]. Interaction of these GAGs with mineralising collagen, the main extracellular matrix component, may be affected, possibly restricting mineral initiation, while binding to the mineral phase could result in less mineral deposition. 


\section{Mineral Phase}

The mineral phase of dentine takes the form of very small apatite crystals $50 \times 70 \times 5 \mathrm{~nm}$, embedded within a highly cross-linked type 1 collagen matrix. There is little direct information on fluorosed or fluorotic dentine mineral. Early reports did, however, suggest that it might contain reduced levels of carbonate and elevated magnesium similar to fluorotic enamel [McCann and Bullock, 1957]. The implications would be related as in enamel to a reduction in the supersaturation levels required for mineral precipitation and crystal growth with a concomitant reduction in acid solubility.

\section{Concluding Remarks}

Despite a very large and often confusing literature concerning the mechanisms which lead to dental fluorosis a relatively clear and well-supported concept is emerging, at least for exposure to concentrations which are not overtly toxic.

It seems likely that, at least in enamel, the effect on the developing mineral phase per se coupled with associated effects on the surrounding and modulating protein matrix could account for most of the observed effects of the fluoride ion on tooth development.

The most obvious feature of fluorosis - impaired growth of apatite crystals - seems attributable to retention of modulating matrix proteins through enhanced binding of mineral to matrix proteins and/or enhanced binding of the proteases responsible for processing prior to matrix removal.
There are still many unanswered questions, however. Information with regard to effects on specific molecular species is still sparse and more detailed studies of the effect of fluoride on the recent unsuspected substructure of apatite crystal surfaces is unclear. With regard to the effect of fluoride on odontogenic cells, the latest information suggests that functional cell structure might be altered at a stage affecting final crystal growth and matrix withdrawal. The following lists include those areas where information is still lacking or unclear.

\section{Avenues for Future Research}

\section{Effect of Fluoride on:}

- Effect of fluoride on cytoskeletal components through the RhoGAP system.

- MAPK kinase phosphatase and similar mitosis-sustaining pathways in odontogenesis cells.

- Relative secretion/amounts of specific protein species with established sequences.

- Alternative splicing of matrix proteins.

- Post-translational processing of specific proteins (phosphorylation, glycosylation, sulphation).

- Post-secretory processing of specific proteins (proteolysis, dephosphorylation, de-glycosylation).

- Surface/molecular morphology of crystals.

- Surface chemistry of crystals (double layer and water structure).

- Specific protein-mineral interactions (motif changes?).

- Regrowth of fluorosed crystals (re-activation of crystal surfaces).

- Effect of increased magnesium on crystal growth.

\section{References}

Aoba T, Fejerskov O: Dental fluorosis: Chemistry and biology. Crit Rev Oral Biol Med 2002;13: 155-170.

Aoba T, Fukae M, Tanabe T, Shimizu M, Moreno EC: Selective adsorption of porcine-amelogenins onto hydroxyapatite and their inhibitory activity on hydroxyapatite growth in supersaturated solutions. Calcif Tissue Int 1987;41:281289.

Aoba T, Moreno EC: The enamel fluid in the early secretory stage of porcine amelogenesis: Chemical composition and saturation with respect to enamel mineral. Calcif Tissue Int 1987;41:8694.
Aoba T, Moreno EC, Tanabe T, Fukae M: Effects of fluoride on matrix proteins and their properties in rat secretory enamel. J Dent Res 1990; 69:1248-1250.

Bachra BE, Fischer HRA: The effect of some inhibitors on the nucleation and crystal growth of apatite. Calcif Tissue Res 1969;3:348-357.

Bronckers ALJ, Jansen LL, Wöltgens JHM: Longterm effects of exposure to low concentrations of fluoride on enamel formation in hamster tooth-germs in organ culture. Arch Oral Biol 1984a;29:811-819.

Bronckers ALJ, Jansen LL, Wöltgens JHM: A histological study of the short-term effects of fluoride on enamel and dentine formation in hamster tooth-germs in organ culture in vitro. Arch Oral Biol 1984b;29:803-810.
Bronckers ALJ, Wöltgens JHM: Short-term effects of fluoride on biosynthesis of enamel-matrix proteins and dentine collagens and on mineralization during hamster tooth-germ development in organ culture. Arch Oral Biol 1985;30: 181-191.

Brookes SJ, Shore RC, Kirkham J, Robinson C: Enzyme compartmentalization during biphasic enamel matrix processing. Connect Tissue Res 1998;39:393-403.

Brown WE, Eidelman N, Tomazic BB: Octacalcium phosphate as a precursor in biomineral formation. Adv Dent Res 1987;1:306-313.

Robinson/Connell/Kirkham/Brookes/ Shore/Smith 
Cooper VK, Ludwig TG: Changes in tooth morphology as affected by fluoridated drinking water. N Z Dent J 1965;61:399-408.

Dean HT, Arnold FA, Elvolve E: Domestic water and dental caries: Additional studies of the relation of fluoride in domestic waters to dental caries in 4425 white children, age $12-14$ years of 13 cities in 4 states. Public Health Rep 1942; 57:1155-1179.

Dean HT, Elvolve E: Further studies on the minimal threshold of chronic endemic dental fluorosis. Public Health Rep 1937;52:1249-1264.

Denbesten PK: Effects of fluoride on protein secretion and removal during enamel development in the rat. J Dent Res 1986;65:1272-1277.

Denbesten PK, Crenshaw MA: The effects of chronic high fluoride levels on forming enamel in the rat. Arch Oral Biol 1984;29:675-679.

Denbesten PK, Crenshaw MA, Wilson MH Changes in the fluoride-induced modulation of maturation stage ameloblasts of rats. J Dent Res 1985;64:1365-1370.

Drinkard CR, Crenshaw MA, Bawden JW: The effect of fluoride on the electrophoretic patterns of developing rat molar enamel. Arch Oral Biol 1983;28:1131-1134.

Eanes ED, Hailer AW: The effect of fluoride on the size and morphology of apatite crystals from physiologic solutions. Calcif Tissue Int 1998; 63:250-257

Eastoe JE, Fejerskov Ø: Composition of mature enamel proteins from fluorosed teeth; in Fearnhead RW, Suga S (eds): Tooth Enamel IV. Amsterdam, Elsevier, 1984, pp 326-330.

Fejerskov Ø, Thylstrup A, Larsen MJ: Clinical and structural features and possible pathogenic mechanism of dental fluorosis. Scand J Dent Res 1977;85:510-534.

Fejerskov Ø, Yaeger JA, Thylstrup A: Microradiography of acute and chronic administration of fluoride on human and rat dentine and enamel. Arch Oral Biol 1979;24:123-130.

Fincham AG, Moradian-Oldak J, Simmer JP: The structural biology of the developing enamel matrix. J Struct Biol 1999;126:270-299.

Fukae M, Tanabe T, Murakami C, Dohi N, Uchida T, Shimizu M: Primary structure of the porcine 89-kDA enamelin. Adv Dent Res 1996;10: 111-118.

Gathercole LJ, Swan AJ, Price G, Dieppe P: Nanometre-scale surface features of arthropathic microcrystals and their relation to protein adsorption: A study by scanning probe microscopy and wide angle X-ray diffraction. J Mater Sci Mater Med 1996;7:511-516.

Gerlach RF, Souza AP, Cury JA, Line SRP: Fluoride effect on the activity of enamel matrix proteinases in vitro. Eur J Oral Sci 2000;108:4853.

Gibson CW, Li Y, Yuan ZA, MacDougall M, Sciutto Kuell $\mathrm{J}$ : The Rho signalling pathway in enamel organ cells. J Dent Res 2003;82:144.

Guy WS, Taves DR, Brey WS: Organic fluorocompounds in human plasma: Prevalence and characterization. Biochemistry Involving Carbon Bonds Am Chem Soc Symp 1976, pp $117-$ 134.
Hall RC, Embery G, Waddington RJ: Modification of the proteoglycans of rat incisor dentinepredentine during in vivo fluorosis. Eur J Oral Sci 2003; 104:286-291.

Hiller CR, Robinson C, Weatherell JA: Variations in the composition of developing rat incisor enamel. Calcif Tissue Res 1975;18:1-12.

Iijima M, Tohda H, Suzuki H, Yanagisawa T, Moriwaki Y: Effects of fluoride on apatite-octacalcium phosphate intergrowth and crystal morphology in a model system of tooth enamel formation. Calcif Tissue Int 1992;50:357-361.

Johnsson MSA, Nancollas GH: The role of brushite and octacalcium phosphate in apatite formation. Crit Rev Oral Biol Med 1992;3:61-82.

Kay MI, Young RA, Posner AS: Crystal structure of hydroxyapatite. Nature 1964;12:1050-1052.

Kerley MA, Kollar EJ: Regeneration of tooth development in vitro following fluoride treatment. Am J Anat 1977;149:181-196.

Khokher MA, Dandona P: Fluoride stimulates [ $\left[{ }^{3} \mathrm{H}\right]$ thymidine incorporation and alkaline phosphatase production by human osteoblasts. Metabolism 1990;39:1118-1121.

Kirkham J, Brookes SJ, Shore RC, Bonass WA, Smith DAM, Wallwork ML, Robinson C: Atomic force microscopy studies of crystal surface topology during enamel development. Connect Tissue Res 1998;38:89-100.

Kirkham J, Brookes SJ, Zhang J, Wood SR, Shore RC, Smith DAM, Wallwork ML, Robinson C: Effect of experimental fluorosis on the surface topography of developing enamel crystals. Caries Res 2001;35:50-56.

Kirkham J, Robinson C, Weatherell JA, Richards A, Fejerskov O, Josephsen K: Maturation in developing porcine enamel. J Dent Res 1988; 67:1156-1160.

Lau WKH, Baylink DJ: Molecular mechanism of fluoride on bone cells. J Bone Miner Res 1990; 13:1660-1667.

Lyaruu DM, De Jong M, Bronckers ALJ, Wöltgens JHM: Ultrastructural study of fluoride-induced in vitro hypermineralisation of enamel in hamster tooth germs explanted during the secretory phase of amelogenesis. Arch Oral Biol 1986;31:109-117.

McCann HG, Bullock FA: The effect of fluoride ingestion on the composition and solubility of mineralized tissues in the rat. J Dent Res 1957; 36:391-398.

Milan AM, Waddington RJ, Embery G: Altered phosphorylation of rat dentine phosphoproteins by fluoride in vivo. Calcif Tissue Int 1999;64:234-238.

Milan AM, Waddington RJ, Embery G: Fluoride alters casein kinase II and alkaline phosphatase activity in vitro with potential implications for dentine mineralization. Arch Oral Biol 2001; 46:343-351

Neuman MF, Mulryan BJ: Synthetic hydroxyapatite crystals. IV. Magnesium incorporation. Calcif Tissue Res 1971;7:133-138.

Nikiforuk G, Grainger RM: Fluoride carbonatecitrate inter-relations in enamel; in Stack MV, Fearnhead RW (eds): Tooth Enamel 1. Bristol, John Wright and Sons, 1965, pp 26-31.
Okazaki $\mathrm{M}: \mathrm{Mg}^{2+}-\mathrm{F}^{-}$interaction during hydroxyapatite formation. Magnesium 1987;6:296301.

Posner AS: Short range order-amorphous precursor in bone: The mineral of bone. Clin Orthop 1985;200:87-99.

Posner AS, Eanes ED, Harper RA, Zipkin I: X-ray diffraction analysis of the effect of fluoride on human bone apatite. Arch Oral Biol 1963;8: 549-570.

Richards A, Kragstrup J, Josephsen K, Fejerskov $\mathrm{O}$ : Dental fluorosis developed in post-secretory enamel. J Dent Res 1986;65:1406-1409.

Robinson C, Briggs HD, Atkinson PJ, Weatherell JA: Chemical changes during development of human deciduous enamel. Arch Oral Biol 1981;26:1027-1033.

Robinson C, Brookes SJ, Shore RC, Kirkham J: The developing enamel matrix: Nature and function. Eur J Oral Sci 1998a;106(suppl 1): 282-291.

Robinson C, Brookes SJ, Wood SR, Kirkham J, Shore RC: The effect of fluoride on the developing mineralised tissues: A brief review. Oralprophylaxe 2003a;25:33-38.

Robinson C, Connell S, Brookes SJ, Shore RC, Kirkham J, Smith DAM: $\mathrm{pH}$ behaviour of biological hydroxyapatite surfaces, apparent $\mathrm{pK}$ values and the effect of fluoride. J Dent Res 2003b:82-83.

Robinson C, Hallsworth AS, Kirkham J: Distribution and uptake of magnesium by developing deciduous bovine incisor enamel. Arch Oral Biol 1984;29:479-481.

Robinson C, Kirkham J: Is the rat incisor typical? INSERM 1984a;125:377-386.

Robinson C, Kirkham J: Enamel matrix components, alterations during development and possible interactions with the mineral phase; in Fearnhead RW, Suga S (eds): Tooth Enamel IV. Amsterdam, Elsevier, 1984b, pp 261-265.

Robinson C, Kirkham J: The effect of fluoride on the developing mineralised tissues. J Dent Res 1990;69:685-691.

Robinson C, Kirkham J, Hallsworth AS: Volume distribution and concentration of protein, mineral and water in developing dental enamel. Arch Oral Biol 1988;33:159-162.

Robinson C, Kirkham J, Shore RC, Brookes SJ, Wood SR: Enamel matrix function and the tuft enigma: A role in directing tissue architecture a partial sequence of human ameloblastin. Chemistry and Biology of Mineralized Tissues, Proc 6th Int Conf 1998b, vol 34, pp 209-213.

Robinson C, Kirkham J, Stonehouse NJ, Shore RC: Control of crystal growth during enamel maturation. Connect Tissue Res 1989;22:139-145.

Robinson C, Kirkham J, Weatherell JA: Fluoride in teeth and bone; in Fejerskov $\varnothing$, Ekstrand $\mathrm{J}$ Burt BA (eds): Fluoride in Dentistry. Copenhagen, Munksgaard, 1996, p 70.

Robinson C, Shore RC, Wood SR, Brookes SJ, Smith DAM, Wright JT, Connell S, Kirkham J: Subunit structures in hydroxyapatite crystal development in enamel: Implications for amelogenesis imperfecta. Connect Tissue Res 2003c;44:1-7. 
Robinson C, Weatherell JAW, Hallsworth AS: Alterations in the composition of permanent human enamel during carious attack; in Leach SA, Edgar WM (eds): Demineralisation and Remineralisation of the Teeth. Oxford, IRL Press, 1983, pp 209-223.

Sasaki S, Takagi T, Suzuki M: Cyclical changes in $\mathrm{pH}$ in bovine developing enamel as sequential bands. Arch Oral Biol 1991;36:227-231.

Simmer JP, Hu JC: Expression structure and function of enamel proteinases. Connect Tissue Res 2002;43:441-449.

Speirs RL: The relationship between fluoride concentrations in serum and in mineralized tissues in the rat. Arch Oral Biol 1986;31:373-381.

Tanabe T, Aoba T, Moreno EC, Fukae M: Effect of fluoride in the apatitic lattice on adsorption of enamel proteins on to calcium apatites. J Dent Res 1988;67:536-542.

Thylstrup A, Fejerskov Ø: Clinical appearance of dental fluorosis in permanent teeth in relation to histological changes. Community Dent Oral Epidemiol 1978;6:315-328.
Uchida T, Murakami C, Dohi N, Wakida K, Satoda T, Takahashi O: Synthesis, secretion, degradation and fate of ameloblastic during the matrix formation stage of the rat incisor as shown by immunocytochemistry using region-specific antibodies. J Histochem Cytochem 1997;45: 1329-1346.

Van der Lugt W, Knottnerus DIM, Young RA: Nuclear magnetic resonance determination of the fluorine position in hydroxyapatite; in Fearnhead RW, Stack MV (eds): Tooth Enamel II. Bristol, John Wright and Sons, 1971, pp 2430

Varughese K, Moreno EC: Crystal growth of calcium apatites in dilute solutions containing fluoride. Calcif Tissue Int 1981;33:431-439.

Walton RE, Eisenmann DR: Ultrastructural examination of various stages of amelogenesis in the rat following parenteral fluoride administration. Arch Oral Biol 1974;19:171-182.

Weatherell JA, Deutsch D, Robinson C, Hallsworth AS: Fluoride concentrations in developing enamel. Nature 1975;256:230-232.

Weatherell J, Deutsch D, Robinson C, Hallsworth AS: Assimilation of fluoride by enamel throughout the life of the tooth. Caries Res 1977;11:85-115.
Wergedal JE, Lau KHW, Baylink DJ: Fluoride and bovine bone extract influence cell proliferation and phosphatase activities in human bone cell cultures. Clin Orthop 1988;233:274-282.

Wright JT, Chen SC, Hall KI, Yamauchi M, Bawden JW: Protein characterization of fluorosed human enamel. J Dent Res 1996;75:19361941

Wright JT, Chen SC, Heffernan LN: Enamel proteases in secretory and maturation enamel of rats ingesting 0 and $100 \mathrm{ppm}$ fluoride in drinking water. Adv Dent Res 1989;3:199-202.

Wu L, Forsling W, Schindler PW: Surface complexation of calcium minerals in aqueous solutions. I. Surface protonation at fluorapatite interfaces. J Colloid Interface Sci 1991;147:178185.

Wu W, Nancollas GH: Kinetics and surface energy approaches to the crystallization of synthetic and biological calcium phosphates. Phosphorus Sulfur Silicon 1999;144-146:125-128.

Yanagisawa T, Takuma S, Tohda H, Fejerskov $\varnothing$, Fearnhead RW: High resolution electron microscopy of enamel crystals in cases of human dental fluorosis. J Electron Microsc 1989;38: 441-448. 